\title{
Розвиток бухгалтерського обліку в умовах впровадження сучасних інформаційних технологій
}

В умовах шостого та сьомого технологічного укладів система бухгалтерського обліку потребує значних змін, каталізатором яких стануть сучасні інформачійні технології. Метою статті є розкриття окремих аспектів розвитку бухгалтерського обліку в умовах ицировізації економіки з використанням інформаційних технологій (штучний інтелект, блокчейн, хмарні сервіси та XBRL). Виявлено, щзо на вітчизняних підприємствах відбувається дублювання принциів пакетних технологій через неповноцінне використання можливостей діалогової обробки інформаиії у програмній системі. Розкрито переваги використання хмарних технологій. Обтрунтовано, щзо блокчейн - ідеальний бухгалтерський облік, адже не допускає помилок або умисних маніпулячій з циффрами шляхом відслідковування усіх фінансових операщій та сповіщення про всі зміни в режимі реального часу. Інформаційні технології здатні обробляти величезні пласти інформації за досить короткий час, тому їх застосування має потужні перспективи у бухгалтерському обліку. Визначено, щзо стримуючими факторами розвитку хмарних технологій в Україні є висока вартість хмарного програмного забезпечення та проблеми доступу через залежність від наявності мережі Інтернет. Відмічено зміни в обліковій методології та практииі, які відбуваються під впливом інформаційних систем та технологій. Зокрема, відбувається «розмивання» професії бухгалтера у технологічному та багатофункиіональному інформаційному середовищі, змінюються підходи до документування господарських операцій, підготовки й оприлюднення фінансової звітності, реалізації функиії контролю в інформаційній системі обліку. Акцентовано увагу на широкому поширенні иифрової фінансової звітності, сформованої за технологією XBRL. Pозкрито прочедуру проведення розрахункових операчій з використанням QR-кодів.

Ключові слова: blockchain, бухгалтерський облік, документування, хмарне сховище, ичифрова фінансова звітність.

DOI https://doi.org/10.33146/2307-9878-2020-1(87)-52-58

A.A. MAKURIN

(Dnipro University of Technology, Dnipro, Ukraine)

\section{Development of Accounting in the Conditions of Introduction of Modern Information Technologies}

In the conditions of the sixth and seventh technological orders, the accounting system requires significant changes, the catalyst of which will be modern information technologies. The purpose of the article is to disclose certain aspects of the development of accounting in a digital economy using information technologies (artificial intelligence, blockchain, cloud services and XBRL). It was revealed that duplication of the principles of packet technologies is occurring at Ukrainian enterprises due to the inferior use of the possibilities of dialogue processing information in a software environment. The advantages of using cloud technologies in accounting were disclosed. It was proved that blockchain is an ideal accounting that does not allow errors or intentional manipulations with numbers by tracking all financial transactions and notifying of all changes in real time. Information technologies are able to process huge volumes of information in a fairly short time, so their application has powerful prospects in accounting. It was determined that the high cost of cloud software and access problems through dependence on the availability of the Internet are the constraining factors for the development of cloud technologies in Ukraine. Changes in accounting methodology and practice that occur under the influence of information systems and technologies were noted. In particular, the profession of an accountant changes in the technological and functional aspect, approaches to documenting business transactions, preparing and publishing financial statements, and implementing the control function in the accounting information system are changing too. The author's focus is on the widespread dissemination of digital financial statements generated using XBRL technology. The procedure for conducting settlement operations using QR codes was disclosed.

Keywords: blockchain, accounting, documentation, cloud storage, digital financial reporting.

\footnotetext{
* Макурін Андрій Андрійович, асистент кафедри обліку і аудиту Національного технічного університету «Дніпровська політехніка» (м. Дніпро), кандидат економічних наук.
} 


\section{Accounting}

Постановка проблеми. Глобалізація, 3 одного боку, відкриває перед людством набір можливостей, зокрема розширення масштабів обміну товарами, послугами, інформацією, технологіями і капіталом, взаємодії в гуманітарній сфері та духовного збагачення особистості. 3 іншого боку - набір загроз через розмежування країн на «цивілізаційний центр» та «периферійну зону», поглиблюючи їхню диференціацію в соціально-економічному і науковотехнічному розвитку, а також скорочення робочих місць у зв'язку з розвитком новітніх технологій [1]. Це стосується і сфери бухгалтерського обліку.

На вітчизняних підприємствах проблемною сферою є дублювання принципів пакетних технологій через неповноцінне використання можливостей діалогової обробки інформації у програмній системі. Переважаючою стала концепція розподіленої обробки 3 подальшим об'єднанням інформації, одержаної 3 окремих робочих місць, для складання зведеної фінансової звітності. Зазначимо, що і до сьогодні для багатьох підприємств інтерес до використання засобів автоматизації управління визначається, перш за все, вирішенням завдань автоматизації процесу складання фінансової звітності. Поява розгалужених мереж філіалів, дочірніх фірм багатьох підприємств привела до виникнення стійкого попиту на так звані корпоративні системи автоматизації, для яких характерна наявність відповідних технологій обробки даних, що дозволяють проводити консолідацію інформації, одержаної від філіалів і підрозділів, при складанні зведеної фінансової звітності.

В умовах шостого та сьомого технологічного укладів система бухгалтерського обліку потребує значних змін, каталізатором яких стануть технології блокчейн та штучного інтелекту. Щодо блокчейн - це база даних, яка для збереження інформації використовує одразу велику кількість різних серверів. Кожен блок «посилається» на попередній, надаючи таким чином доступ не тільки до власної інформації, але і до тієї, що зберігається у попередньому блоці. При зміні даних в одному блоці система одразу визначає, що вони відрізняються від даних у інших блоках, та повідомляє про це. По суті, блокчейн - сам собі бухгалтер. Особливістю системи є постійна перевірка даних у блоках, сповіщення за умови їхньої зміни та водночас записування нової інформації у новий блок. Блокчейн - ідеальний бухгалтерський облік, адже не допускає помилок або умисних маніпуляцій з цифрами шляхом відслідковування усіх фінансових операцій та сповіщення про всі зміни в режимі реального часу [2]. Вище зазначене підтверджує необхідність впровадження блокчейн в бухгалтерську практику. Це тренд, який повільно, але впевнено набуває популярності.

Про вагомість використання цієї технології свідчать можливості іiі впровадження в діяльність державних регуляторів США для контролю фінансових операцій. Таким чином, спеціалісти, здатні складати звітність через систему блокчейн, незабаром цінуватимуться вище, ніж бухгалтери, що працюють $з$ традиційними програмами обліку.
Технології штучного інтелекту використовуються на практиці в різних секторах економіки. Враховуючи, що ключовою особливістю технологій штучного інтелекту є здатність обробляти величезні пласти інформації за досить короткий час, їх застосування має потужні перспективи у бухгалтерському обліку, зокрема при зборі, обробці та аналізі даних під час проведення різноманітних досліджень. До можливостей і переваг належить здатність самостійно і швидко готувати різноманітні бухгалтерські звіти.

Аналіз останніх досліджень і публікацій. Розвиток ефективних комп'ютерних технологій постійно перебуває у центрі багатьох наукових досліджень. Питаннями пов'язаними 3 функціонуванням інформаційних технологій у обліку займались вітчизняні вчені. Серед ним можна зазначити В.О. Осмятченко та В.С. Олійник, які досліджували тенденції розвитку бухгалтерського обліку в контексті зміни технологічних укладів. Вчені наголошують на проведенні досліджень пов'язаних 3 використанням хмарних технологій та технології блокчейн для проведення господарських операцій [3]. I.O. Спільник та М.А. Палюх досліджували питання 3 організації бухгалтерського обліку в умовах цифрової економіки. Особливу увагу науковці приділяють усвідомленню ризиків, переосмислення ролі та місця обліку в цифровому середовищі. Також значну роль має формування навої парадигми обліку та облікової системи на підприємстві у зв'язку з впровадженням віртуальних та хмарних технологій [4; 15]. О.І. Халевський, М.Л. Варламова оцінили вплив цифрової трансформації суспільства на трудові ресурси в України та в світі. Визначили основні передумови реформування банківської сфери за допомогою технології блокчейн. Дослідники зазначають, що сучасна цифрова трансформація відбувається завдяки впровадженню в бізнес середовище штучного інтелекту, технології блокчейн. Це дозволяє збільшити цільову аудиторію, зменшити операційні витрати та прискорити проведення операцій однорівневого характеру [5]. Основні переваги та недоліки використання блокчейн технології в процесі управління поставками досліджували О.В. Позднякова та О.І. Петренко. Слід зазначити особливий вплив технологічного прогресу на адаптування підприємства до потреб ринку завдяки налагодженню комунікацій та системи обміну інформації в режимі реального часу завдяки програмному забезпеченню [6].

Метою статті $\epsilon$ розкриття окремих аспектів розвитку бухгалтерського обліку в умовах цифровізації економіки 3 використанням сучасних інформаційних технологій (штучний інтелект, блокчейн, хмарні сервіси та XBRL).

Методика дослідження. Для досягнення поставленої мети автором використано такі методи і прийоми теорії пізнання як аналіз і синтез, встановлення причинно-наслідкових зв'язків розвитку процесів і явищ. 
Виклад основного матеріалу. Системи штучного інтелекту вже використовують найбільші аудиторські та фінансові компанії шляхом програм і мобільних додатків для певних розрахунків та аналізу даних. Такі технології досі ще використовуються для вирішення вузького кола завдань, але спектр їхніх можливостей 3 кожним роком розширюється.

Ще однією тенденцією бухгалтерського обліку в умовах шостого технологічного укладу $\epsilon$ використання хмарних технологій, які набувають більшого поширення та мають ряд переваг [7] (рис. 1). Під хмарними технологіями потрібно

\section{Бухгалтерський облік}

розуміти спроектоване та надане у комерційне користування віртуальне програмне середовище (сервери, комп'ютери, сервіси), розгорнуте у хмарі на базі обчислювальних потужностей, розміщених у дата-центрах провайдера хмарних сервісів.

Основними категоріями хмарних обчислень є: інформаційні технології як послуга (IT as a service, ITaaS) та програмне забезпечення (ПЗ) як послуга (Software as a Service, SaaS). Хмарні технології, зокрема бухгалтерські SaaS-рішення, набувають значної популярності в Україні [8].

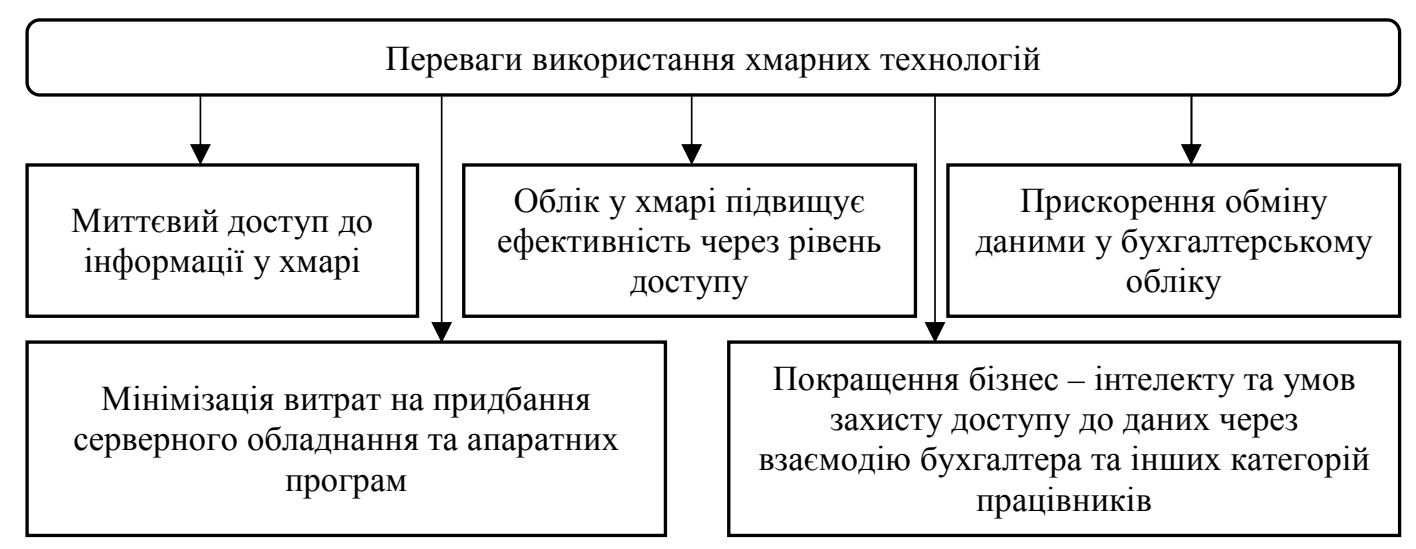

Рuc. 1. Переваги використання хмарних технологій

Джерело: складено автором.

До стримуючих факторів розвитку хмарних технологій в Україні потрібно віднести: високу вартість хмарного програмного забезпечення; проблеми доступу через залежність від наявності мережі Інтернет.

Вище зазначене свідчить про необхідність розробок організаційно-методичних положень для застосування зазначених технологій на практиці 3 метою вирішення конкретних облікових завдань, зокрема створення віртуальних офісів звідповідними централізованими сховищами первинної і звітної документації.

Під впливом інформаційних систем та технологій відбуваються знані зміни в обліковій методології та практиці. В умовах інформатизації суспільства облік може втратити свою особливість відносно основної ролі, постачальника економічної інформації. Відбувається процес розмивання професії бухгалтера у технологічному та багатофункціональному інформаційному середовищі. Протягом значного періоду в обліку накопичилися проблеми пов'язані зі зниженням функціональної складової обліку, що зумовлено його консервативністю та спрямованістю інформації. Основна теза цього процесу домінування процесу над результатом, а також недосконалість інформаційної цінності облікової інформації для зацікавлених користувачів. Тому важливою умовою для подальшого розвитку обліку $є$ підвищення рівня відповідності його інформації запитам користувачів.
Бухгалтерський облік як процес починається 3 виявлення, вимірювання і реєстрації фактів, дій та подій 3 метою отримання інформації про господарські операції та діяльність підприємства в цілому. Суцільне і безперервне спостереження за всіма господарськими операціями на підприємстві здійснюється до допомогою документування. Це один 3 основних методів обліку. Таким чином, документ $\epsilon$ важливою складовою процесу обліку, оскільки виступає матеріальним носієм інформації, який засвідчує факти 3 відображення діяльності підприємства. Особливо важливим на сучасному етапі розвитку є використання блокчейн технології у обліку. Оскільки саме вона дозволяє швидко $\mathrm{i}$ безпечно здійснювати документообіг з клієнтами та контрагентами. На сьогодні відомо три основні способи документообігу між двома особами:

- класичний ( передача інформації за допомогою паперових носіїв);

- за допомогою електронної пошти;

- за допомогою надавання доступу до хмарного сховища.

Звичайно кожен із зазначених способів має свої недоліки. Наприклад, основним недоліком класичного способу виступають високі матеріальні витрати та низька швидкість відтворення. Тобто, необхідно використовувати допомогу сторонніх осіб (листоноша, кур'єрська служба) при передачі інформації в такій операції [4]. Основним недоліком при використанні електронної пошти є створення 


\section{Accounting}

певних умов за для ऑii використання. Тобто, насамперед необхідно здійснити умовні обговорення тих чи інших угод, оскільки при затверджені необхідно отримати підписи обох сторін. Але для набуття юридичної сили необхідно роздрукувати документ та залучити класичний спосіб, або ЕЦП за допомогою сторонньої програми. Використання хмарного сховища має таку ваду, як незахищеність. Такий централізований сервер має певну незахищеність та $є$ нестійким до системних помилок чи хакерських атак. Наприклад при використанні технології blockchain кожен блок даних має свій умовний пароль, натомість при хмарному зберіганні досить володіти ключем від центрального сервера.

Таким чином, вагомим надбанням цифрової економіки $є$ використання технологій пов'язаних 3 безконтактною ідентифікацією інформації, до якої можна віднести карткові, біометричні технології, технології штрихованого коду, мовленнєве введення даних та машинного зору. QR - коди є простим, зручним та інтерактивним способом розповсюдження і отримання інформації. Завдяки використанню такої технології значну кількість інформації можна закодувати та поширити, а за допомогою камери смартфону розпізнати цю інформацію.

На вітчизняних підприємствах проблемною сферою є дублювання принципів пакетних технологій через неповноцінне використання можливостей діалогової обробки інформації у програмній системі. Переважаючою стала концепція розподіленої обробки 3 подальшим об'єднанням інформації, одержаної 3 окремих робочих місць, для складання зведеної фінансової звітності.

Інформування підприємства про наявність та стан необоротних активів виступає пріоритетним напрямом облікової та контрольно - аналітичної роботи підприємства. Оскільки володіння такими матеріальними цінностями вимагає знаних інвестицій. Стан їх впливає на об'єм випуску готової продукції, а це в свою чергу - на недоодержання доходів. У великих компаніях збирання, оброблення даних щодо наявності, стану та повної інформації про об'єкти обліку являють собою дуже затяжний процес. Таке поставлене керівництвом завдання виконують різні підрозділи у межах своїх повноважень [7]. Тому виникає проблема в узагальненні отриманих даних 3 двох підрозділів .

Для покращення та спрощення проведених внутрішніх операцій на підприємстві можна використати QR - кодування та нанести певні зображення на кожен об'єкт. При зчитуванні даних за допомогою смартфону 3 таких штрих кодів інформація формується у загальний блок 3 джерел різних підрозділів. Тому керівництво буде отримувати повну та достовірну інформацію, що сприяє швидкому прийняттю рішень. Крім цього, якщо використати певні «датчики» на кожен об'єкт, то в режимі реального часу машинний інтелект зможе відслідковувати стан об'єктів і в разі потреби втручання сповістити про це працівника.

В українському законодавстві не існує визначення QR-коду. Так, на підставі ст. 2 Закону України «Про застосування реєстраторів розрахункових операцій у сфері торгівлі, громадського харчування та послуг» від 06.07.1995 р № 265/95-ВР (далі - Закон про РРО) розрахунковою операцією $є$, зокрема, приймання від покупця платіжних карт за місцем реалізації товарів (послуг) та оформлення відповідного розрахункового документа щодо оплати в безготівковій формі товару (послуги) банком покупця. При цьому згідно зі ст. 3 Закону про РPO, суб'єкти господарювання, які здійснюють розрахункові операції в безготівковій формі при продажу товарів (наданні послуг) у сфері торгівлі, громадського харчування та послуг, зобов'язані:

- проводити розрахункові операції на повну суму покупки (надання послуги) через зареєстровані, опломбовані в установленому порядку та переведені у фіскальний режим роботи РРО з роздрукуванням відповідних розрахункових документів, що підтверджують виконання розрахункових операцій, або у випадках, передбачених Законом про РPO, із застосуванням зареєстрованих у встановленому порядку розрахункових книжок;

- видавати особі, яка отримує або повертає товар, отримує послугу або відмовляється від неї, включаючи ті замовлення оплата яких здійснюється 3 використанням мережі Інтернет, при отриманні товарів (послуг) в обов'язковому порядку розрахунковий документ встановленої форми на повну суму проведеної операції.

Серед бухгалтерських програм для ведення обліку на підприємстві при використанні хмарного сховища та підтримки QR - кодів можна зазначити наступні (табл. 1).

В системі «1С: Підприємство 8» реалізований національний стандарт штрих-кодування платіжних реквізитів, розроблений Некомерційним партнерством «Національна платіжний рада». Це дозволяє здійснювати платежі швидко і без помилок.

Процедура оплати передбачає три етапи:

1) В системі «1С: Підприємство 8» друкується платіжний документ з QR-кодом;

2) Платник виробляє оплату шляхом автоматичного сканування даних зручним для нього способом (платіжний термінал; мобільний інтернетбанк; відділення банку);

3) Грошові кошти за надані послуги надходять на рахунок одержувача.

При цьому виключена ймовірність помилкової прив'язки платежу до чужого особистому рахунку - в QR-коді міститься вся інформація, необхідна для однозначного визначення як споживача, так i постачальника послуг [8]. Оплачуючи свої рахунки за квитанціями 3 двовимірним кодом, платник може бути спокійний, адже його гроші обов'язково дійдуть за призначенням. 
Сучасні програми бухгалтерського обліку

\begin{tabular}{|c|c|c|}
\hline Назва & Можливості програми & Підтримка QR кодів \\
\hline $\begin{array}{l}\text { «1С: } \\
\text { Підприємство 8» }\end{array}$ & $\begin{array}{l}\text { Забезпечує віддалене підключення через веб-інтерфейс } \\
\text { розподілених підрозділів системи. Можливість } \\
\text { формувати і надавати електронну звітність засобами } \\
\text { мережі Інтернет }\end{array}$ & $\begin{array}{l}\text { Iснує } \quad \text { штрих } \\
\text { платіжних реквізитів. }\end{array}$ \\
\hline «Парус» & Ведення обліку можливе і в хмарному середовищі & $\begin{array}{ll}\text { Функціонування } & \text { штрих-кодів } \\
\text { ускладнено } & \text { програмним } \\
\text { забезпеченням } & \\
\end{array}$ \\
\hline «Діловод» & Цілодобовий доступ з будь-якого місця, де $є$ Інтернет & $\begin{array}{l}\text { Підтримує роботу зі штрих- } \\
\text { кодами }\end{array}$ \\
\hline «iFin» & $\begin{array}{l}\text { Дозволяє здійснити підготовку і подачу звітності. Вести } \\
\text { складський облік. Усі дані зберігаються на Windows } \\
\text { Azure за межою України }\end{array}$ & $\begin{array}{l}\text { Підтримує роботу зі штрих- } \\
\text { кодами }\end{array}$ \\
\hline
\end{tabular}

Джерело: розроблено автором.

Необхідно розглянути функціонування сучасних систем та мовних стандартів для формування фінансової звітності. Наприклад, значного поширення у світі та в Україні набули стандарти формування звітності в електронному вигляді. Цей стандарт має назву XBRL (eXtensible Business Reporting Markup Language та $\epsilon$ розширеною мовою ділового звітування. Ця технологія забезпечує швидке й автоматичне формування звіту, також значно спрощує формування консолідованої звітності. Однією з основних переваг є спрощений пошук даних фінансової звітності у мережі Інтернет. Формат XBRL однаково зручний як для подання обов'язкової звітності в державні контролюючі органи, так і для представлення звітів на веб-сайтах підприємств.

Таким чином, цифрова фінансова звітність - це звітність сформована 3 використанням сучасних інформаційно - технологічних систем персонального комп'ютеру. Для іiї перевірки використовується комп'ютерна система, яка унеможливлює допущення помилки та виключає людський фактор.

Під час розробки такої системи особливу увагу приділено «таксономії фінансової звітності». Це перелік певних статей та основних показників фінансової звітності та іiі елементів, які необхідно розкрити та показати їх взаємозв'язок 3 іншими елементами таксономії. На виконання статті 1 Закону України «Про бухгалтерській облік та фінансову звітність в Україні» Міністерством фінансів України прийнято наказ від 07.12 .2018 р. № 983 «Про затвердження перекладу таксономії фінансової звітності за міжнародними стандартами фінансової звітності» [9].

Особлива вимога, яка висувається до такого програмного забезпечення - це надання певного «людського досвіду та розуміння» балансовому звіту та звіту про прибутки та збитки, збір основної інформації для розкриття, трансформація активів у балансі та формування даних про найбільш ліквідні 3 них, дотримання основного рівняння балансу, згідно якого активи повинні дорівнювати зобов'язанням та капіталу. Доступ до цифрової фінансової звітності надається користувачам в електронному форматі, який поширюється сучасним засобами комунікації. Така інформація не потребує декодування, а регулятори, фінансові та державні органи, бізнесові системи отримують однакове розуміння зв'язків між зареєстрованими фактами господарських операцій.

Для того щоб машина була спроможна прочитати цифрову фінансову звітність необхідно інтегрувати в неї людські знання щодо механізму формування фінансового звіту. Тобто усі знання необхідно формалізувати [10]. Більшість суб'єктивних знань, наприклад такі як професійне судження бухгалтера, ще нікому не вдалось виразити в певних термінах, які були б зрозумілі для техніки. Таким чином, персональний комп'ютер імітує діяльність людини та виконує усі механічні завдання, пов'язані 3 формуванням фінансового звіту. Отже, усі рутинні механічні процеси бухгалтер передає обчислювальній техніці, а за собою залишає право контролю процесів зі складання фінансових звітів.

Якщо сучасний світ змінюється у зв'язку 3 розвитком інформаційних систем і технологій, то зміни повинні відбутися і в традиційних методах обліку. Оскільки останні не можуть бути статистичними й непорушними, адже розвивається сама система обліку. Відтак необхідно зберегти методологічне ядро обліку, а розвивати коло використаних методів, забезпечувати їх відповідність викликам сьогодення.

Інтерес до технології блокчейн (Blockchain), яка змінює світ так само сильно, як це свого часу зробив Інтернет, 3 боку усіх цивілізованих держав та міжнародних установ зростає 3 кожним днем. До списку лідерів іiі впровадження ввійшли США, Канада, Бразилія, Австралія, Ізраїль, ОАЕ, Грузія, Естонія, Велика Британія, Франція, Німеччина. Не стала винятком і Україна, для якої масштаби і темпи цифрових трансформацій повинні стати ключовими характеристиками розвитку країни, а починаючи 3 2016 року цю технологію поступово впроваджують у різних галузях [12].

Розвиток цифрових технологій та винайдення системи блокчейн впливає на методи обліку. Так наприклад, як зазначає Deloitte: «Замість формування 


\section{Accounting}

i локального зберігання певних трансакційних записів, суб'єкти мають можливість записувати їх в єдиний реєстр, що дозволяє створити певну взаємопов'язану систему 3 надійної бухгалтерської інформації». Практично неможливо знищити такі записи або фальсифікувати, оскільки всі вони мають криптографічну захищеність [13]. Тобто мова вже йде, не про подвійний запис у обліку, а про потрійний. Принципово змінюється спосіб реєстрації та зберігання інформаційної бази 3 фактів господарських операцій, яка 3 легкістю може трансформуватися в базу узагальнених даних, фінансових і нефінансових звітів. Все це у своєму поєднанні утворює інформаційний ресурс глобального інформаційного економічного середовища.

Висновки. На вітчизняних підприємствах через неповноцінне використання діалогової обробки інформації у програмній системі відбувається дублювання принципів пакетних технологій. Використання хмарних технологій покращує ведення бухгалтерського обліку та дозволяє спростити облікові процеси. Стримуючим фактором впровадження хмарних технологій в Україні є висока вартість хмарного програмного забезпечення та проблеми постійного доступу до мережі Інтернет.

Аналізуючи технологію блокчейн виявлено, що вона $є$ ідеальним бухгалтерським обліком, оскільки не допускає помилок та сповіщає про всі зміни в реальному часі. Перспективою використання інформаційних технологій у бухгалтерському обліку $\epsilon$ те, що вони дозволяють обробляти величезні пласти інформації та в подальшому формувати фінансову звітність. Формат XBRL цифрової фінансової звітності зручний як для подання обов'язкової звітності в державні контролюючі органи, так і для представлення звітів на веб-сайтах підприємств. Для iї перевірки використовується комп'ютерна система, яка унеможливлює допущення помилки та виключає людський фактор.

\section{4 Список використаних джерел}

1. Blockchain: A technical primer. Deloitte. February 6, 2018. URL: https://www2.deloitte.com/ insights/us/en/topics/emergingtechnologies/blockchaintechnical-primer.html.(дата звернення 18. 03. 2020)

2. Brukhanskyi R., Spilnyk I. "Cryptographic Objects in the Accounting System", Proceedings of 9th International Conference on Advanced Computer Information Technologies, ACIT'2019, pp. 384-387.

3. Осмятченко В. О., Олійник В. С. Стан та перспективи розвитку бухгалтерського обліку в контексті зміни технологічних укладів. Економічний вісник. Серія: Фінанси, облік, оподаткування. 2018. №. 2. C. 131-138.

4. Спільник I., Палюх М. Цифровий формат фінансової звітності: сутність, переваги, перспективи. Цифрова економіка: тренди та перспективи: матеріали міжнар. наук.-практ. конф., м. Тернопіль, 25 жовтня.
5. Халевський О. І. Цифрова трансформація в міжнародній банківській сфері. Вісник студентського наукового товариства ДонНУ імені Василя Стуса. 2019. Т. 1. №. 11. С. 226-230.

6. Познякова О. В., Петренко О. І. Переваги та недоліки використання блокчейн-технології в управлінні ланцюгами поставок. Bratislava. 2019. C. 113 .

7. Про схвалення Концепції розвитку цифрової економіки та суспільства України на 2018-2020 роки та затвердження плану заходів щодо іiі реалізації: Розпорядження Кабінету Міністрів від 17.01.2018 р. № 67-p. URL: https://zakon.rada.gov.ua/laws/show. (дата звернення 25. 03. 2019)

8. Радівілова Г., Спільник I. QR-кодування в обліку та управлінні активами підприємства: переваги та перспективи використання. Цифрова економіка: тренди та перспективи: матеріали Міжнародної науково-практичної конференції [Тернопіль, 25 жовтня 2018 р.]. Тернопіль: Осадца Ю. B., 2018. C. 319-320. URL: http://dspace.tneu.edu.ua/ handle/316497/32851 (дата звернення 25. 03. 2020)

9. Про затвердження перекладу таксономії фінансової звітності за міжнародними стандартами фінансової звітності: Наказ Міністерства фінансів України від 07.12.2018 p. № 983. URL: https://www.minfin.gov.ua/news/view/pro-zakhodyshchodo-skladaformati?category=bjudzhet \& subcategory=taksonomiia (дата звернення 20. 03. 2020)

10. Khorunzhak N., Brukhanskyi R., Ivanyshyn V. Logic-statistical information models in control function of accounting. Independent Journal of Management\&Production. 2019. Vol 10, No 7. P. 846871. DOI: http://dx.doi.org/10.14807/ijmp.v10i7.906

11. Digital Financial Reporting. URL: https://en.wikibooks.org/wiki/Digital_Financial_Reporting (дата звернення 22. 03. 2020)

12. Crypto Currency Market Capitalisation, CoinMarketCap website. URL: https://coinmarketcap.com (дата звернення 22. 03. 2020)

13. KPMG report: 'cryptoassets are now impossible to ignore' but there are still challenges facing institualization. URL: https://www.theblockcrypto.com/ 2018/11/19/kpmg-report-cryptoassets-are-nowimpossible-to-ignore-but-there-are-still-challengesfacing-institutionalization/ (дата звернення 22. 03. 2020)

14. Івахненков С. В. Електронні технології звітування як передумова аналізу та контролю фінансової звітності. Облік і фінанси АПК. 2008. № 4. C. 67-76.

15. Павлюковець М. П. Теоретико-методологічні засади запровадження клоуд-комп'ютерної форми обліку. Облік і фінанси АПК. 2012. № 1. С. 149-151.

\section{References}

1. Deloitte. (February 6, 2018). Blockchain: A technical example. Retrievied from https://www2.deloitte.com/insights/us/en/topics/emerging -technologies/blockchain-technical-primer.html (accessed 18 March 2020) 
2. Brukhanskyi, R. \&, Spilnyk, I. (2019). Cryptographic Objects in the Accounting System (pp. 384-387). In Proceedings of 9th International Conference on Advanced Computer Information Technologies, ACIT'2019,

3. Osmjatchenko, V. O., Olijnyk, V. S. (2018). Stan ta perspektyvy rozvytku bukhghaltersjkogho obliku v konteksti zminy tekhnologhichnykh ukladiv [Status and prospects of accounting development in the context of changing technological ways]. Ekonomichnyj visnyk. Serija: Finansy, oblik, opodatkuvannja, (2), 131-138.

4. Spilnyk, I., \& Palyukh, M. (2018). Tsyfrovyy format finansovoyi zvitnosti: sutnist, perevahy, perspektyvy [Digital format of financial statements: the essence, advantages, prospects] (pp. 115-117). In Tsyfrova ekonomika: trendy ta perspektyvy: materialy mizhnar. nauk.-prakt. konf., m. Ternopil, 25 zhovtnya 2018 r. Ternopil: FOP Osadtsa Yu. V. Retrievied from:http://dspace.tneu.edu.ua/handle/316497/32763

5. Khalevsjkyj, O. I. (2019). Cyfrova transformacija $\mathrm{v}$ mizhnarodnij bankivsjkij sferi [Digital transformation in the international banking sector]. Visnyk studentsjkogho naukovogho tovarystva DonNU imeni Vasylja Stusa. Vol. 1, (11), 226-230.

6. Poznjakova, O. V., Petrenko, O. I. (2019). Perevaghy ta nedoliky vykorystannja blokchejntekhnologhiji v upravlinni lancjughamy postavok [Advantages and disadvantages of using blockchain technology in supply chain management], Bratislava, 113.

7. Kabinet Ministriv Ukrainy. (17.01.2018). Pro skhvalennia Kontseptsii rozvytku tsyfrovoi ekonomiky ta suspilstva Ukrainy na 2018-2020 roky ta zatverdzhennia planu zakhodiv shchodo yii realizatsii [Approval of the Conceptfor the Development of the DigitalEconomy and Society of Ukrainefor 2018-2020 and approval of the plan of measuresforitsimplementation]. Retrievied from https://zakon.rada.gov.ua/laws/show

8. Radivilova, H. \& Spilnyk, I. (2018). QRkoduvannya $\mathrm{v}$ obliku ta upravlinni aktyvamy pidpryyemstva: perevahy ta perspektyvy vykorystannya [QR-coding in the accounting and asset management of the enterprise: advantages and prospects of use] (pp. 319-
Бухгалтерський облік

320). In Tsyfrova ekonomika: trendy ta perspektyvy: materialymizhnar. nauk.-prakt. konf., m. Ternopil, 25 zhovtnya 2018 r. Ternopil: FOP Osadtsa Yu. V. Retrievied from http://dspace.tneu.edu.ua/ handle/316497/32851

9. Ministerstvo finansiv Ukrayiny. (07.12.2018). Pro zatverdzhennya perekladu taksonomiyi finansovoyi zvitnosti za mizhnarodnymy standartamy finansovoyi zvitnosti: [Approval of Financial Statements Taxonomy Translation of According to International Financial Reporting Standards]. Retrievied from https://www.minfin.gov.ua/news/view/pro-zakhodyshchodo-skladannia-finansovoi-zvitnosti-na-osnovitaksonomii-finansovoi-zvitnosti-v-iedynomuelektronnomu-formati?category=bjudzhet\&subcategory =taksonomiia

10. Khorunzhak, N., Brukhanskyi, R., Ivanyshyn, V. (2019). Logic-statistical information models in control function of accounting. Independent Journal of Management \& Production, Vol 10, (7), 846-871. DOI: http://dx.doi.org/10.14807/ijmp.v10i7.906

11. Digital Financial Reporting. Retrievied from https://en.wikibooks.org/wiki/Digital_Financial_Reporting

12. Crypto Currency Market Capitalisation, Coin Market Capwebsite. Retrievied from https://coinmarketcap.com

13. KPMG report: 'cryptoassets are now impossible to ignore' but there are still challenges facing institualization. Retrievied from https://www.theblockcrypto.com/2018/11/19/kpmgreport-cryptoassets-are-now-impossible-to-ignore-butthere-are-still-challenges-facing-institutionalization/

14. Ivakhnenkov, S. V. (2008). Elektronni tekhnolohiyi zvituvannya yak peredumova analizu ta kontrolyu finansovoyi zvitnosti. [Electronic reporting technologies as a prerequisite for the analysis and control of financial reporting]. Oblik i finansy APK, (4), 67-76.

15. Pavliukovets, M. P. (2012). Teoretykometodolohichni zasady zaprovadzhennia kloudkompiuternoi formy obliku [Theoretical bases of introduction of the cloud-computer form of the accounting]. Oblik i finansy APK, (1), 149-151. 